\title{
Gold Plate Electrodes Functionalized by Multiwall Carbon Nanotube Film for Potentiometric Thallium(I) Detection
}

\author{
Saad S. M. Hassan ${ }^{1, *}$, Sabah. M. Abdelbasir ${ }^{2}{ }^{(}$, M. Abdelwahab Fathy $^{1}{ }^{\mathbb{D}}$, \\ Abd El-Galil E. Amr 3,4,*D, Mohamed A. Al-Omar ${ }^{3}(\mathbb{D})$ and Ayman H. Kamel 1,* \\ 1 Chemistry Department, Faculty of Science, Ain Shams University, Abbasia 11566, Cairo, Egypt \\ 2 Electro Chemical Treatment Dept., Central Metallurgical Research and Development Institute (CMRDI), \\ P.O. Box 87, Helwan 11421, Cairo, Egypt \\ 3 Pharmaceutical Chemistry Department, Drug Exploration \& Development Chair (DEDC), \\ College of Pharmacy, King Saud University, Riyadh 11451, Saudi Arabia \\ 4 Applied Organic Chemistry Department, National Research Center, Dokki 12622, Giza, Egypt \\ * Correspondence: saadsmhassan@sci.asu.edu.eg (S.S.M.H.); aamr@ksu.edu.sa (A.E.-G.E.A.); \\ ahkamel76@sci.asu.edu.eg (A.H.K.); Tel.: +20-1222162766 (S.S.M.H.); +966-565-148-750(A.E.-G.E.A.); \\ $+20-1000743328$ (A.H.K.)
}

Received: 22 June 2019; Accepted: 1 August 2019; Published: 14 August 2019

\begin{abstract}
Solid-contact potentiometric ion-selective electrodes (SC-ISEs) for thallium determination have been designed using multiwall carbon nanotubes (MWCNTs) as the ion-to-electron transducer. Dispersed MWCNTs were drop-casted over a gold plate electrode. Two different crown ethers were used in the sensing membrane for the recognition of thallium (I). Sensorsbased on dibenzo-18-crown-6 (DB18C6) as a neutral carrier and NaTPB as an anionic additive exhibited a near Nernstian response of $57.3 \mathrm{mV} /$ decade towards $\mathrm{Tl}^{+}$ions over the activity range $4.5 \times 10^{-6}-7.0 \times 10^{-4} \mathrm{M}$, with a limit of detection of $3.2 \times 10^{-7} \mathrm{M}$. The time required to achieve $95 \%$ of the steadyequilibrium potential was $<10 \mathrm{~s}$. The complex formation constant $\left(\log \beta_{M L}\right)$ between dibenzo-18-crown- 6 and thallium (I) (i.e., 5.99) was measured using the sandwich membrane technique. The potential response was $\mathrm{pH}$ independent over the range 3.0-9.5. The introduction of MWCNTs as an electron-ion-transducer layer between gold plate and the sensing membrane lead to a smaller membrane resistance and a large double layer capacitance, which was proven using impedance spectra and chronopotentiometry (i.e., $114.9 \pm 12 \mathrm{k} \Omega, 52.1 \pm 3.3 \mathrm{pF}, 200 \pm 13.2 \mathrm{k} \Omega$, and $50 \pm 4.2 \mu \mathrm{F}$ ). Additionally, reduction ofthe water layer between the sensing membrane and the underlying conductor wastested. Thus, it is clear that MWCNTs can be used as a transducing layer in SC-ISEs. The proposed sensor was introduced as an indicator electrode for potentiometric titration of single and ternary mixtures $\mathrm{of} \mathrm{I}^{-}, \mathrm{Br}^{-}$, and $\mathrm{S}^{2-}$ anions.
\end{abstract}

Keywords: solidcontact ISEs; thallium; ion-to-electron transducer; multiwall carbon nanotubes (MWCNTs)

\section{Introduction}

Natural processes and human activity increase the concentration of metals in the environment. This poses a threat to human and other living organisms. One of the most significantpollutants that isintroduced and affects the environment is thallium ( $\mathrm{Tl}$ ), which is produced as waste from lead and coal combustion [1]. Thallium is the most dangerous pollutant, with a higher toxicity to the biosphere than $\mathrm{Cd}, \mathrm{Cu}, \mathrm{Hg}$, and $\mathrm{Pb}$ [2]. It is used in the manufacture of low-temperature thermometers, optical lenses, semiconductors, jewelry, and as a catalyst in certain alloys [3]. Thallium (I) sulfate is also used as 
an insecticide and for rat poison [4]. Soluble thallium (I) compounds, e.g., thallium nitrate, acetate, and carbonate are dangerous because absorption within the body by ingestion or skin contact leads to high toxicity [5]. Athalliumconcentration of $0.5 \mathrm{mg} / 100 \mathrm{~g}$ of tissue can be regarded as thallium poisoning [5].

From a biological and environmental point of view, determination of thallium (I) ion concentration has become a major concern for researchers. There are several techniques that have been used to determine thallium (I) ion in solution, including differential pulse anodic stripping voltammetry (DPASV) [6,7], square wave anodic stripping voltammetry (SWASV) [8], flame atomic absorption spectrometry (FAAS) [9], emission spectrometry [10], inductively coupled plasma (ICP) [11,12], graphite furnace atomic absorption spectrometry (GFAAS) [13], and spectrophotometry [14]. Despite the sensitivity of these methods, they suffer from the need for expensive instrumentation. For this reason, the need for low-cost, simple, miniaturized, and accurate analytical techniques for Tl determination becomes a strong requirement. Ion-selective electrodes (ISEs) have been used extensively as potentiometric sensors in chemical analysis for several analytes $[15,16]$. Conventional or symmetrical ISEs, for which there is an inner filling solution that acts as a conducting electrolyte between the inner reference electrode and the ion selective membrane (ISM), suffer from drawbacks such aslack ofportability, largesize, and their need for routinemaintenance, thus limiting their wider applications [17,18].

On the other hand, solid-state ion-selective electrodes have abandoned the internal filling solution by coating the ISM directly onto the solid conducting substrates. Consequently, some of the drawbacks mentioned above have been eliminated [19]. The first example of solid-state ISEs was a coated-wire electrode (CWE), which was invented in the 1970s [20]. However, these types of electrode have the disadvantage of poor long-term potential stability. This can be attributed to the indefinite phase boundary potential at the interface between the metallic substrate and the sensing membrane. To solve this problem, an intermediate layer was used to act as an ion-to-electron transducer between the metallic substrate and the sensing membrane, and significant efforts have been made to investigate the effective transducer layers [21]. To date, many solid contact layers such as carbon, conducting polymers, and nobel metal materials have been reported [22-24].

However, these systems have some limitations, including limited selectivity, the need for calibration, and potential drift, so they require significant improvement. Certainly, it is clear that the potential stability is the most important aspect. There are two reasons for the potential drift: the water layer formation between the ISM and the solid substrate, and the non-zero current. In the first case, due to poor adhesion of the membrane to the substrate, the sensor is affected by osmolality variations, which leads to delamination during operation [20]. Nanomaterials have many advantages as a solid contact overconducting polymers, which suffer from the possibility of side-reactions, lower conductivity compared to the nanomaterials, and a sensitivity to light and $\mathrm{pH}$ [25].

In the systems containing nanomaterials, the interfacial potential is related to the amount of charge accumulated in the double layer, not to ion partitioning as in symmetrical ISEs, or to reduction-oxidation reactions as in the case of using conducting polymers. Nano-structured material prevents the risk of water absorption and enables the achievement of good adhesion because of their hydrophobic behavior and large surface area. Furthermore, they form large double layer capacitance values, which reduce the effect of polarization due to non-zero currents [26]. Nobel metals and carbon nanostructures have been investigated for use as solid-contacts for ISEs. Examples of these carbon nanostructures are porous carbon [27], carbon nanotubes [28-31], graphene [31-33], fullerene [34,35], and three-dimensionally ordered macroporous (3DOM) carbon [36,37]. These carbon-nanostructure materials are chemically stable and exhibit high specific surface areas. Examples of nobel metals are platinum nanopetals [38], gold nanoparticles [39,40], and gold nano-clusters [41]. Besides the solid-contact itself, the choice of electron conducting substrate is also important. The nature of the electron conductor substrate has an effect on the interface between this substrate and the solid-contact material. The equilibration times of all-solid-state ISEs using different electron-conducting substrates (i.e., glassy carbon, Au, and Pt) were tested [42]. Sensors using glassy carbon and Au as electron conducting substrates exhibited much shorter equilibration times than electrodes made from Pt substrate. Similarly, sensors made with Au 
substrates were also reported to exhibit higher $E^{\circ}$ reproducibility than those based on glassy carbon substrates [43].Therefore, careful consideration should be taken inthe choice of the electron-conducting substrate (i.e., glassy carbon, $\mathrm{Au}$, and $\mathrm{Pt}$ ) when designing solid-contact ISEs.

In this work, miniaturized solid-contact potentiometric ion-selective electrodes (SC-ISEs) for $\mathrm{Tl}^{+}$determination are presented for the first time. The sensor membranes are based on the use of dibenzo-18-crown-6 (DB18C6) as a neutral carrier. Multiwall carbon nanotubes (MWCNTs) are used as a solid contact material on a gold film (i.e., electron-conducting substrate). The constructed $\mathrm{Tl}^{+}$-SC-ISEs exhibit high potential stability and small membrane impedance. This simple fabrication of the electrode design permits the fabrication of these ISEs by a non-specialist. The developed SC/T1 ${ }^{+}$-ISEs are fully characterized and tested in potentiometric titration of single and ternary mixtures of $\mathrm{I}^{-}, \mathrm{Br}^{-}$, and $\mathrm{S}^{2-}$ ions. As a consequence of the excellent analytical performance, we conclude that this technology may become promising for the design of in-situ $\mathrm{Tl}^{+}$sensing probes.

\section{Materials and Methods}

\subsection{Equipment}

Potential measurements were performed with an Orion (Cambridge, MA, USA) Model 720/SA pH/mV meter at $25 \pm 1{ }^{\circ} \mathrm{C}$ using the gold plate thallium polymeric membrane sensor in conjunction with $\mathrm{Ag} / \mathrm{AgCl}$ double-junction reference electrode (Orion 90-20) filled with $1 \mathrm{M}$ $\mathrm{CH}_{3} \mathrm{COOLi}$. Chronopotentiometry and electrochemical impedance spectroscopy (EIS) measurements were carried out using a potentiostat/galvanostat (Autolab Model 2000, Metrohom Instruments, Herisau, Switzerland). A three-electrode configuration cell containing a silver/silver chloride ( $3 \mathrm{M} \mathrm{KCl})$ reference electrode and an auxiliary electrode made from platinum wire was employed. The impedance spectra were measured and recorded at open-circuit potential in a $0.01 \mathrm{M} \mathrm{NaClO}_{4}$ solution with an excitation amplitude of $10 \mathrm{mV}$ and a frequency range of $100 \mathrm{kHz}-0.1 \mathrm{~Hz}$.

\subsection{Materials and Reagents}

All chemicals and reagents used were of analytical grade and were used as received and prepared with de-ionized water. For membrane preparation, high molecular weight poly (vinyl chloride) (PVC), O-nitrophenyloctyl ether (o-NPOE), Tetrahydrofurane (THF), and sodium tetraphenylborate (NaTPB) were used as received from Fluka or Merck. Multiwall carbon nanotubes (MWCNTs) were purchased from (EPRI, cairo, Egypt). Sodium sulphide $\left(\mathrm{Na}_{2} \mathrm{~S}\right)$, sodium iodide $(\mathrm{NaI})$, sodium bromide $(\mathrm{NaBr})$, and Trizma ${ }^{\circledR}$ buffer were purchased from Sigma Aldrich. A $0.1 \mathrm{M}$ stock solution of $\mathrm{TlNO}_{3}$ was freshly prepared.

\subsection{Preparation of Gold Plate Electrodes}

Gold plate electrodes (GPEs) witha gold diameter of $4 \mathrm{~mm}$ and a purity of $99.999 \%$ were sonicated for $10 \mathrm{~min}$ in acetone then cleaned by isopropanol and ethanol, each for $10 \mathrm{~min}$. De-ionized water was then used to rinse the electrodes for $5 \mathrm{~min}$, which were then left for 2 hto dry. Commercial multiwalled carbon nanotubes (MWCNTs) with a diameter of 1-20 nm were sonicated for 30 min with tetrahydrofuran (THF) in order to get a good dispersion for the carbon nanotubes (CNTs) [44,45]. Using a micropipette, droplets of the CNTs solution with THF were dropped over the gold plate electrode. As a result, CNTs were uniformly deposited over the gold plate electrode. It was then left for $2 \mathrm{~h}$ for drying by evaporation of tetrahydrofuran from the electrode.

\subsection{Sensor Construction}

The ion selective membranes were prepared by dissolving appropriate amounts of ionophores, $\mathrm{NaTPB}$ as an anionic additive, o-NPOE as a plasticizer, and PVC in THF $(3 \mathrm{~mL})$ as recommended bythe Internatioal Union of pure Applied chemistry (IUPAC) [46]. $50 \mu \mathrm{L}$ of the homogenous membrane cocktail was drop-casted on the gold plate electrode directly, or on the CNTs deposited on the gold plate 
electrode, using a micropipette and then leftfor $2 \mathrm{~h}$ for drying by the evaporation of tetrahydrofuran as shown in Figure 1. Thereafter, the sensors were conditioned by soaking them in a $0.01 \mathrm{M}$ aqueous solution of $\mathrm{TlNO}_{3}$ for $12 \mathrm{~h}$.

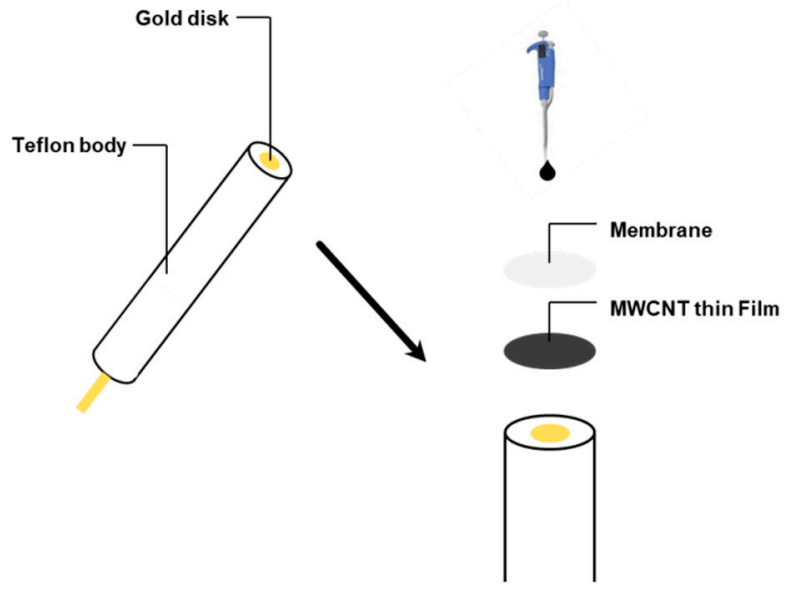

Figure 1. Sensor construction using multiwalled carbon nanotubes (MWCNTs)

\subsection{Potential Measurements}

The proposed ISE was calibrated using a standard two electrode (working and reference) cell configuration, using a gold plate electrode and a $\mathrm{CNT} /$ gold plate electrode in conjunction with an $\mathrm{Ag} / \mathrm{AgCl}$ reference electrode. The cell solution contentsof $10.0 \mathrm{~mL}$ of $0.01 \mathrm{M}$ Trizma buffer $(\mathrm{pH} \sim 6)$ and (0.5-1.0) $\mathrm{mL}$ aliquots of a $1.0 \times 10^{-1}-1.0 \times 10^{-7} \mathrm{M}$ from an aqueous solution of $\mathrm{Tl}^{+}$were sequentially added. After potential stabilization, the readings were plotted as a function of log $\mathrm{a}_{\mathrm{Tl}+}$. Estimation of $\mathrm{Tl}^{+}$concentration was done using the calibration plot.

\subsection{Complex Formation Constants Measurements}

According to the sandwich membrane method, experiments were carried out [47,48]. The PVC/plasticizer (1:2) membranes containing $80 \mathrm{mmol} / \mathrm{kg}$ of ionophore and $56 \mathrm{mmol} / \mathrm{kg}$ of NaTPB (total membrane mass $100 \mathrm{mg}$ ) were cast. Additionally, membranes without ionophore were prepared by the same constituents. A $50 \mu \mathrm{L}$ of the membrane cocktail was drop-casted from both types of membrane and then conditioned overnight in a $0.01 \mathrm{M}$ solution of the appropriate salt $\left(\mathrm{Tl}^{+}, \mathrm{K}^{+}, \mathrm{Pb}^{2+}, \mathrm{Na}^{+}, \mathrm{NH}_{4}{ }^{+}\right)$. The membrane with the ionophore faced to the sample solution. The membranes were then instantly placed into a salt solution that was identical to the conditioning of the membrane. The mean potential was recorded for the last minute of a 10 min measurement period in the test solution. In a separate measurement, the potential of an electrode with the membrane containing no ionophore was measured in the same solution. The formation constant $\left(\log \beta_{M L}\right)$ was calculated according to Equation $(1)[47,48]$ :

$$
\log \beta_{M L}=\frac{E_{M} \cdot z_{I} F}{2.303 \cdot R T}-n \log \left(L_{T}-\frac{n}{z_{I}} R_{T}\right),
$$

where $n$ is the complex stoichiometry, $L_{T}$ is the total concentration of ionophore, $R_{T}$ is the concentration of the lipophilic ionic site additives, and $R, T$, and $F$ are the gas constant, the absolute temperature, and the Faraday constant, $Z_{I}$ charge of the tested ion. The membrane potential $E_{M}$ is determined by subtracting the cell potential for the membrane without ionophore from that of the sandwich membrane. 


\section{Results and Discussions}

\subsection{Performace Characterisics of the Proposed Sensors}

Attempts were made to use two different crown ethers as neutral carriers for the $\mathrm{Tl}^{+}$ion in the PVC matrix membrane sensors. For ISEs based on neutral carriers, the potentiometric selectivity depends mainly on the ability of the neutral carrier to extract the desired ion [49,50]. According to the previously reported studies for solvent extraction [51], some crown ether derivatives revealed good complexing ability towards the $\mathrm{Tl}^{+}$ion. In this work, dibenzo-18-crown-6 (DB18C6) was tested as a neutral carriers for designing a miniaturized SC/Tl' ${ }^{+}$ISEs. MWCNTs were used as an intermediate layer between the sensing membrane and $\mathrm{Au}$, which acts as an electron conductor substrate. The membrane composition was $32.0 \mathrm{wt}$ \% PVC, $65.0 \mathrm{wt}$ \% plasticizer, and $3.0 \mathrm{wt}$ \% \% ionophore. Potentiometric characteristics of sensors based on DB18C6 revealed a strong response towards $\mathrm{Tl}^{+}$ions. Results from replicate studies showed sub-Nernstian slopes of $32.7 \pm 2.5 \mathrm{mV} /$ decade, with detection limits of $4.0 \times 10^{-6} \mathrm{M}$, respectively. The addition of $1.5 \mathrm{wt}$ \% $\mathrm{Na}-\mathrm{TPB}$ enhanced the sub-Nernstian calibration slope from $32.7 \pm 2.5$ to a Nernstian slope of $57.3 \pm 1.6 \mathrm{mV} /$ decade and lowered the detection limit from $4.0 \times$ $10^{-6} \mathrm{M}$ to $3.2 \times 10^{-7} \mathrm{M}$. The addition of NaTPB as lipophilic anions to the membrane improved its performance characteristics, because it stabilizes membrane operating conditions, decreases membrane resistance, and significantly reduces response times. The calibration plots of these ISEs are shown in Figure 2, and their performance characteristics are presented in Table 1. The potential responses revealed by the proposed sensors can be attributed to the selective interaction of $\mathrm{Tl}^{+}$ions with DB18C6 and are affected by: (i) The ionic diameter of the crown ionophore; (ii) the ionic size of the thallium (I) ion; and (iii) the spatial configuration of this ionophore. The ionic size of $\mathrm{Tl}^{+}$is $1.73 \AA$, while the ionic diameters of both 18-crown-6 varies from 2.6-3.2 $\AA$ [52].

Table 1. Potentiometric response characteristics of $\mathrm{Tl}^{+} \mathrm{PVC}(\mathrm{o}, \mathrm{NPOE})$ membrane sensors based ondibenzo-18-crown-6 (DB18C6).

\begin{tabular}{|c|c|c|}
\hline \multirow{2}{*}{ Parameter * } & \multicolumn{2}{|c|}{ Ionophore } \\
\hline & DB18C6 & DB18C6 + Anionic Additive \\
\hline Slope, (mV/decade) & $32.7 \pm 2.5$ & $57.3 \pm 1.6$ \\
\hline Correlation coefficient, $(\mathrm{r})$ & 0.9864 & 0.9998 \\
\hline Intercept, $(\mathrm{mV})$ & 179.5 & 366.2 \\
\hline Linear range, $(\mathrm{M})$ & $7.9 \times 10^{-6}-7.0 \times 10^{-4}$ & $4.5 \times 10^{-6}-7.0 \times 10^{-4}$ \\
\hline Detection limit, (M) & $4.0 \times 10^{-6}$ & $3.2 \times 10^{-7}$ \\
\hline Working range, $(\mathrm{pH})$ & $3.0-9.5$ & $3-9.5$ \\
\hline Response time for $10^{-3} \mathrm{M},(\mathrm{s})$ & $<10$ & $<10$ \\
\hline Accuracy $(\%)$ & 98.7 & 99.2 \\
\hline Repeatability $\left(\mathrm{CV}_{\mathrm{W}}, \%\right)$ & 0.9 & 0.7 \\
\hline Between-day-Variability $\left(\mathrm{CV}_{\mathrm{b}}, \%\right)$ & 1.1 & 1.2 \\
\hline
\end{tabular}

* Mean of 3 measurements.

The response time of the sensor was also tested by measuring the time required to achieve a $95 \%$ steady potential for all concentration ranges $\left(10^{-6}-10^{-2} \mathrm{M} \mathrm{TlNO}_{3}\right.$ solutions). Fairly short response times of $5 \mathrm{~s}$ for $\left[\mathrm{Tl}^{+}\right]>10^{-5} \mathrm{M}$ and $10 \mathrm{~s}$ for $\left[\mathrm{Tl}^{+}\right] \leq 10^{-5} \mathrm{M}$ were obtained (Figure 2). A drop in the sensitivity was observed after 1 week of reasonably stable behavior.

The $\mathrm{pH}$ dependence of the DB18C6+TPB membrane based sensor was tested using two $\mathrm{Tl}^{+}$ concentrations (i.e., $10^{-3}$ and $10^{-4} \mathrm{M}$ ). A stable potential response was noticed over the $\mathrm{pH}$ range 3-9.5, as shown in Figure 3. A pH adjustment was carried out using dilute $\mathrm{LiOH}$ and $\mathrm{HNO}_{3}$. Below pH 3, the potential drift observed is attributed to either the response of $\mathrm{SC} / \mathrm{Tl}^{+}$-ISEs to $\mathrm{H}^{+}$ions, or it may be due to the protonation of the ionophore itself in the membrane. The observed potential drop above $\mathrm{pH} 9.5$ is attributed to the formation of $\mathrm{TlOH}$ precipitate.

Potentiometric selectivity coefficients $\left(\log { }^{P o t} T l+, j\right)$ for the sensor were evaluated using the modified separate solution method (MSSM) [53]. Before measuring the potential response of all tested ions, the 
membrane had never been in contact with the primary ions. In order of decreasing discrimination, we first started with the most discriminated ions. The highest measured concentrations $\left(10^{-1} \mathrm{M}\right)$ were used for the estimation of the selectivity values [53]. The activities of both $\mathrm{Tl}+$ and the interfering ions were calculated by the extended Deby-Huckel equation. The results are shown in Figure 4 . The selectivity order of the sensor was found to be: $\mathrm{Tl}^{+}>\mathrm{K}^{+}>\mathrm{Pb}^{2+}>\mathrm{NH}_{4}{ }^{+}>\mathrm{Li}^{+}>\mathrm{Cu}^{2+} \approx \mathrm{Sr}^{2+} \approx \mathrm{Ca}^{2+}>$ $\mathrm{Ni}^{2+} \approx \mathrm{Na}^{+}>\mathrm{Zn}^{2+} \approx \mathrm{Ag}^{+} \approx \mathrm{Co}^{2+} \approx \mathrm{Ba}^{+}>\mathrm{Mg}^{2+} \approx \mathrm{Fe}^{2+}>\mathrm{Cd}^{2+}$. It can be seen that the sensor reveals enhanced selectivity towards $\mathrm{Tl}^{+}$ions over many of the ions under investigation, so the designed sensor is appropriate for the intended estimations.

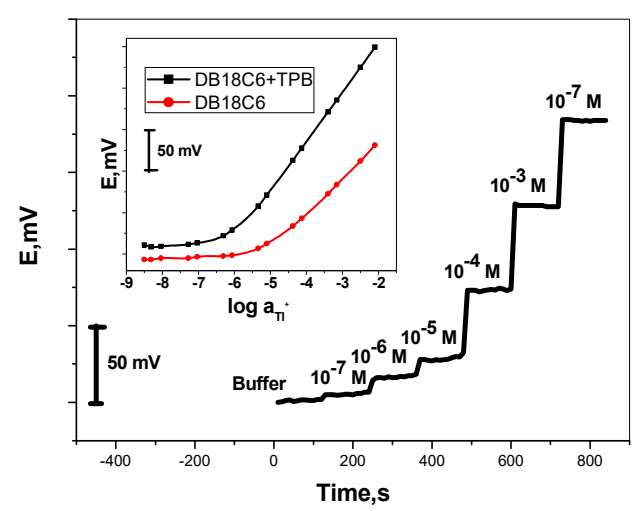

Figure 2. Time trace of the proposed sensors. Insert: Calibration curves of these ion sensors.

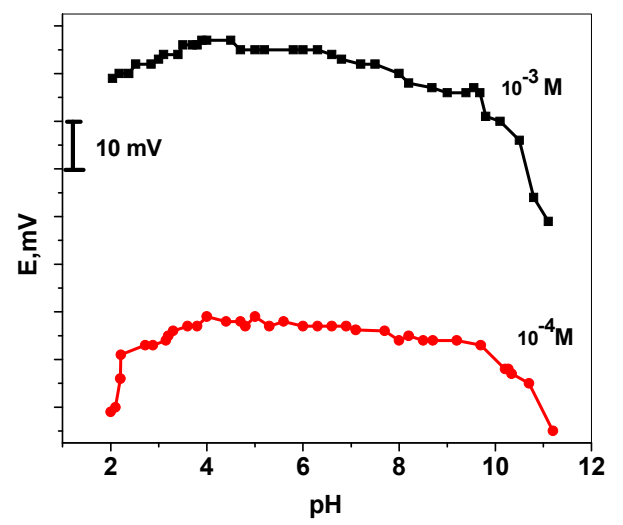

Figure 3. Effect of $\mathrm{pH}$ on the response of the sensor.

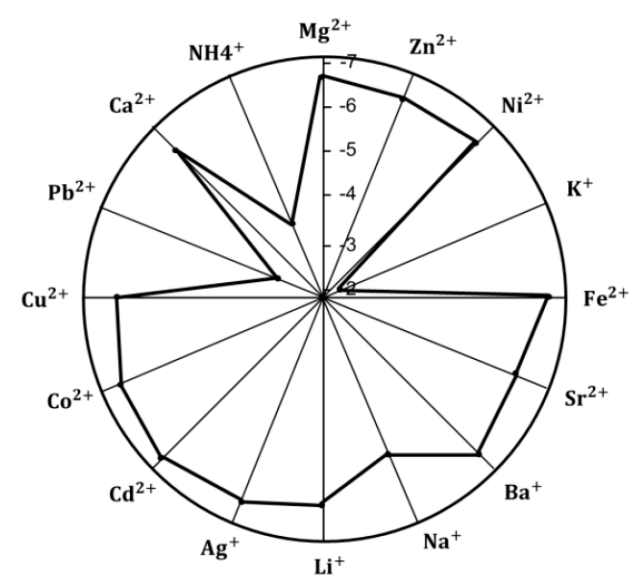

Figure 4. Selectivity coefficient ( $\log \mathrm{k}_{\mathrm{Tl}, \mathrm{J}}^{\text {pot }}$ ) values of the proposed sensor using modified separate solution method (MSSM). 


\subsection{Formation Constant $\beta_{M L}$}

The potentiometric selectivity of the polymeric membranes is related to the differences in the lipophilicity of the ions, the membrane composition, and the stability constant [54]. As the last factor is typically the most important one, several methods suitable for the estimation of stability constant values in the membrane phase were proposed [47,48]. Among them, the sandwich membrane method seems to be the most appropriate due to its simplicity and reliability. In this work, various cations and dibenzo-18-crown- 6 formation constants were determined. The obtained results are presented in Table 2. It was found that the $\mathrm{Tl}^{+}$ion can form the strongest complex with dibenzo-18-crown-6. The complex stability constants, $\log \beta_{M L}$, measured for other cations, are significantly lower compared to thallium, while the values of $\log \beta_{M L}$ for $\mathrm{K}^{+}$and $\mathrm{Pb}^{2+}$ are nearly the same.

Table 2. Complex formation constants, $\log \beta_{M L}$ of dibenzo 18-crown-6 with various cations, measured in $o$-NPOE plasticized poly (vinyl chloride) membranes.

\begin{tabular}{cccccc}
\hline Ion & $\begin{array}{c}\text { Atomic Radius } \\
(\AA)\end{array}$ & $\begin{array}{c}\text { Ionophore } \mathbf{L}_{\mathbf{T}} \\
(\mathbf{m m o l} / \mathbf{K g})\end{array}$ & $\begin{array}{c}\text { Additive } \\
(\mathbf{m m o l} / \mathbf{K g})\end{array}$ & $\begin{array}{c}\text { Membrane } \\
\text { Potential } \mathbf{\Delta E}(\mathbf{m V})\end{array}$ & $\begin{array}{c}\text { Formation } \\
\text { Const.Log } \boldsymbol{\beta}_{\mathbf{I L}}\end{array}$ \\
\hline $\mathrm{Tl}^{+}$ & 2.2 & 80 & 56 & $258.30 \pm 3$ & $5.99 \pm 0.6$ \\
$\mathrm{~K}^{+}$ & 2.8 & 80 & 56 & $252.39 \pm 5$ & $5.89 \pm 0.8$ \\
$\mathrm{~Pb}^{2+}$ & 2.02 & 80 & 56 & $255.48 \pm 1$ & $5.81 \pm 0.7$ \\
$\mathrm{NH}_{4}^{+}$ & 1.40 & 80 & 56 & $193.00 \pm 3$ & $4.88 \pm 0.3$ \\
$\mathrm{Na}^{+}$ & 2.27 & 80 & 56 & $174.06 \pm 1$ & $4.56 \pm 0.4$ \\
\hline
\end{tabular}

\subsection{Water Layer Test}

The water layer, which is formed between the underlying conductor and the ISM, leads to some failures, the most important of which are responsive hysteresis, potential instability, and mechanical problems [19,24]. A simple protocol was presented byPretsch et al. [55] in order to confirm the presence of the water layer between the sensing membrane and the electron conducting substrate. The possible drift by replacing the primary ions solution can be observed with discriminated interfering ions, and the reverse is true in the presence of this layer of water. When interfering ions are replaced by primary ions, or vice versa, either a possible negative or positive potential driftis obtained. This is due to the transfer of the corresponding ions from the samples spread over the ISM, which leads to a change in the composition of the water layer [19,24].

Herein, tests for the reduction of the water layer after the insertion of the lipophilic MWCNT layers were carried out. Sequential immersions of the gold plate electrode in the presence and absence of the MWCNT layer in $1.0 \times 10^{-2} \mathrm{M}$ Trizma buffer $(\mathrm{pH} \sim 6)$ solution was done for the first hour then in a $1.5 \times 10^{-5} \mathrm{M}$ Tl (I) solution for the second hour, then in $1.0 \times 10^{-2} \mathrm{M}$ Trizma buffer (pH 6) solution for the third hour, then in $2.5 \times 10^{-6} \mathrm{M} \mathrm{Tl}$ (I) solution, then in $1.0 \times 10^{-2} \mathrm{M}$ Trizma buffer $(\mathrm{pH} \sim 6)$ solution. The data obtained are illustrated in Figure 5. In the case of the electrode without the MWCNT layer, positive potential drift was observed with a positive potential drift of $\sim 26 \mathrm{mV}$ in $1 \mathrm{~h}$. Subsequently, when the solution was changed to the $1.5 \times 10^{-5} \mathrm{M} \mathrm{Tl}$ (I) solution, a negative potential drift of $15 \mathrm{mV}$ occurred for the second hour, while using $\mathrm{Tl}$ (I) concentration $\left(2.5 \times 10^{-6} \mathrm{M}\right)$ a positive potential drift of $5 \mathrm{mV}$ occurred. Notably, in the case of the presence of the MWCNT layer (GPE/MWCNTs), nearly no significant potential drifts $(\approx 5 \mathrm{mV})$ were observed when the measured solution was changed from $1.5 \times 10^{-5} \mathrm{M}$ to $2.5 \times 10^{-6} \mathrm{M}$. From all of the above results, we can verify that a reduced water layer is formed between the underlying gold plate, the MWCNT layer, and the ISM.This also proves the high hydrophobicity of the intermediate multiwall carbon nano-tube uniform layer. 


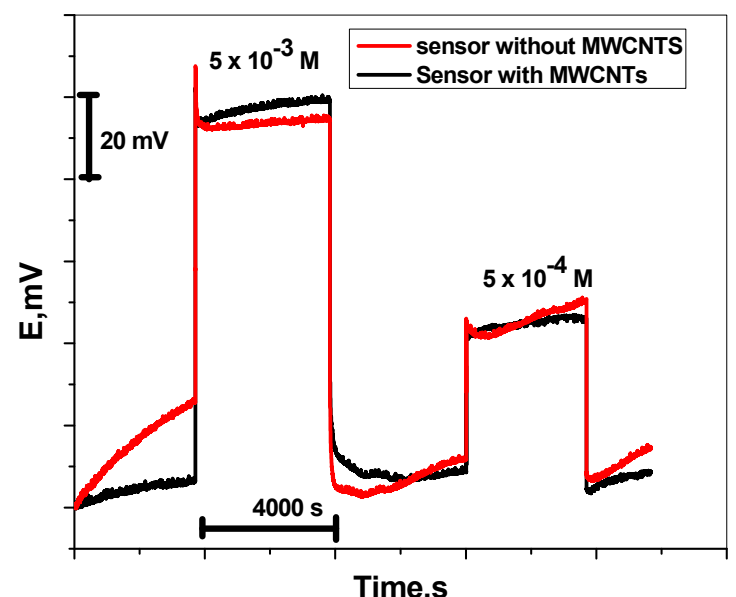

Figure 5. Water layer test for Tl membrane based sensor in the absence and presence of MWCNTs.

\subsection{Chronopotentiometric Test}

At a constant current of $\pm 1 \mathrm{nA}$, chronopotentiograms were recorded to verify the potential stability of the developed GPE/MWCNTs, and the results are clearly shown in Figure 6. As can be seen in the case of GPE in the absence of MWCNTs, there is a large potential drift of up to $100 \pm 0.01 \mu \mathrm{V} / \mathrm{s}(n=3)$. Nevertheless, in the case of GPE/MWCNTs, a much smaller potential drift value of $16 \pm 0.02 \mu \mathrm{V} / \mathrm{s}$ $(n=3)$ is recorded for the SC-ISE. Due to the high double layer capacitance of MWCNTs, this is likely to result in potential stability. Using the method provided by Bobacka [56], the membrane resistance and capacitance of the ISE can be calculated. According to the fundamental equations: $\Delta E / \Delta t=i / C$ and $\Delta E=I R$, in which $\Delta E, \Delta t, I, C$, and $R$ represent the change of potential, variation of time, applied current, capacitance, and bulk membrane resistance, respectively, the capacitances in the absence and presence of MWCNTs were calculated to be $23.8 \pm 5.1$ and $57.8 \pm 1.3 \mu \mathrm{F}$, respectively. The resistances of the membrane in the absence and presence of the MWCNT layer were $393 \pm 9.1$ and $100 \pm 6.3 \mathrm{k} \Omega$, respectively. From the results shown above, we can confirm the relationship between the potential stability and the presence of the MWCNT layer as a solid contact.

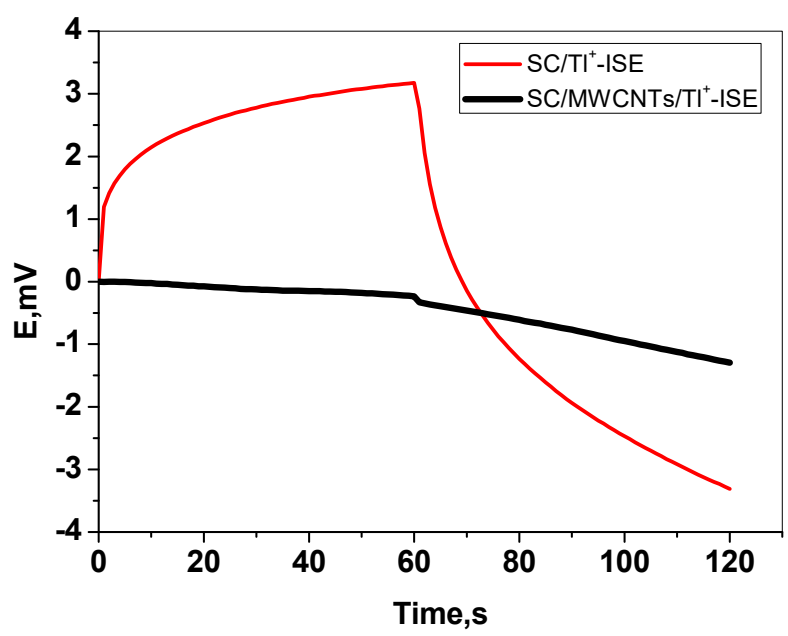

Figure 6. Chronopotentiograms for the solid-contact(SC/Tl ${ }^{+}$-ISE) (top) and SC/MWCNTs/ $/ 1^{+}$-ISE (bottom) electrodes under the constant currents of $\pm 1 \mathrm{nA}$ in $1.5 \times 10^{-5} \mathrm{M}$ of $\mathrm{Tl}^{+}$solution.

\subsection{Electrochemical Impedance Spectroscopy (EIS) Measurements}

The electrochemical impedance spectrum for gold plate electrode (GPE) in the presence and absence of MWCNTs as an ion-to-electron transducer were measured by EIS measurements. The obtained EIS 
plots are shown in Figure 7. The bulk membrane resistance, together with contact resistance between the underlying conductor and the ISM, is represented by the diameter of the semicircle at the high frequency region, represented by $R_{b c}$, in parallel with the combined geometric capacitance $\left(C_{g}\right)$ [57]. While at the low-frequency region, characteristics are attributed to the double-layer capacitance $\left(C_{d}\right)$ coupled with a charge-transfer resistance $\left(\mathrm{R}_{\mathrm{ct}}\right)$ at the interface between the ISM and the underlying conductor [57]. After inserting the MWCNT layer, a small $R_{b c}$ can be obtained for the GPE/MWCNTs $\left(R_{b c}=114.9 \pm 12 \mathrm{k} \Omega\right.$ ) when compared with the GPE in the absence of MWCNTs $\left(R_{b c}=418 \pm 11.2 \mathrm{k} \Omega\right.$ ). The geometric capacitances $\left(\mathrm{C}_{\mathrm{g}}\right)$ for GPE in the absence and presence of MWCNTs are $52.1 \pm 3.3$ and $141.8 \pm 7.4 \mathrm{pF}$. At the low frequency region, the charge-transfer resistance $\left(\mathrm{R}_{\mathrm{ct}}\right)$ and double-layer capacitance $\left(\mathrm{C}_{\mathrm{dl}}\right)$ for GPE in the absence and presence of MWCNTs are $R_{\mathrm{ct}}=454.5 \pm 13.2 \mathrm{k} \Omega, \mathrm{Cd}=22 \pm 2.1 \mu \mathrm{F}$ and $R_{c t}=200 \pm 13.2 \mathrm{k} \Omega, C_{d}=50 \pm 4.2 \mu \mathrm{F}$, respectively. As a result, the presence of MWCNTs as an ion-to-electron transducer offers higher potential stability. This is because of the presence of the MWCNT layers, which facilitate the charge transport between interfaces in the SC-ISEs.

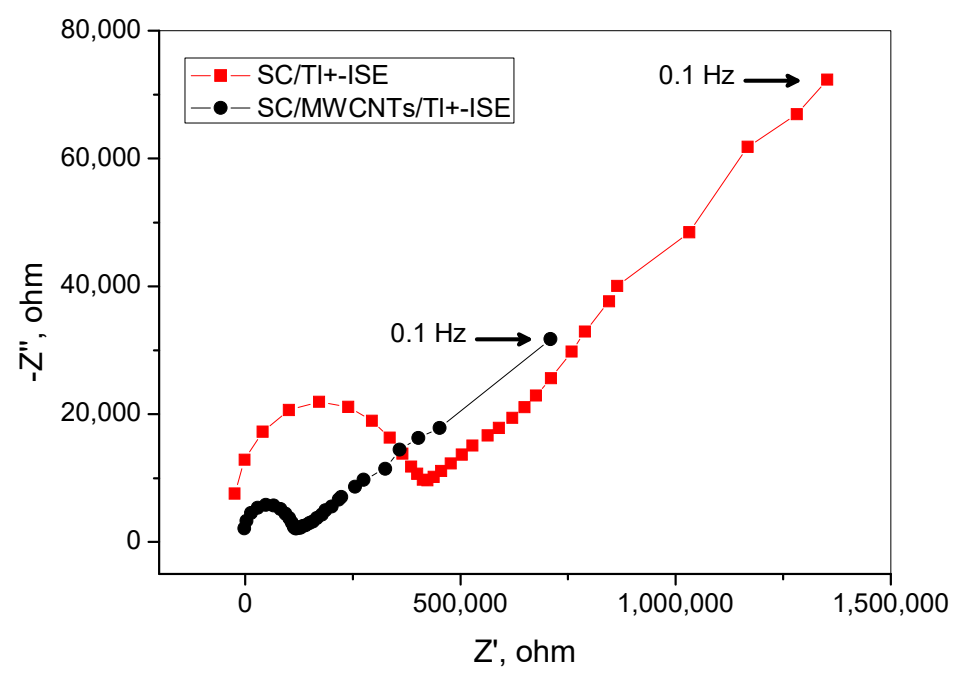

Figure 7. Electrochemical impedance spectroscopy (EIS)spectra of the SC/MWCNTs/Tl ${ }^{+}$-ISE with (circles) and SC/ $\mathrm{Tl}^{+}$-ISE (squares) without the solid-contact layer of MWCNTs measured in $1.5 \times 10^{-5}$ Tl (I) solution.

\subsection{Analytical Application}

The proposed sensor was successfully applied as an indicator electrode in the potentiometric precipitation titration of the $\mathrm{Na}_{2} \mathrm{~S}, \mathrm{NaBr}$, and $\mathrm{NaI}$ solutions with $\mathrm{TlNO}_{3}$. Typical results for the titration of $50.0 \mathrm{~mL}$ of $2 \times 10^{-3} \mathrm{M} \mathrm{S}^{2-}, 1 \times 10^{-3} \mathrm{M} \mathrm{Br}^{-}$, and $\mathrm{I}^{--}$solutions of each of them singly and ternary against $0.01 \mathrm{M} \mathrm{TlNO}_{3}$ are shown in Figure 8a-d. It is clear that the concentration of sulfide, bromide, and iodide ions in solution can be accurately determined from the resulting neat titration curve providing a sharp end point.The solubility product of each salt is responsible for the obtianed inflection break, and is the controller for the order and sloping of the potential jump. 


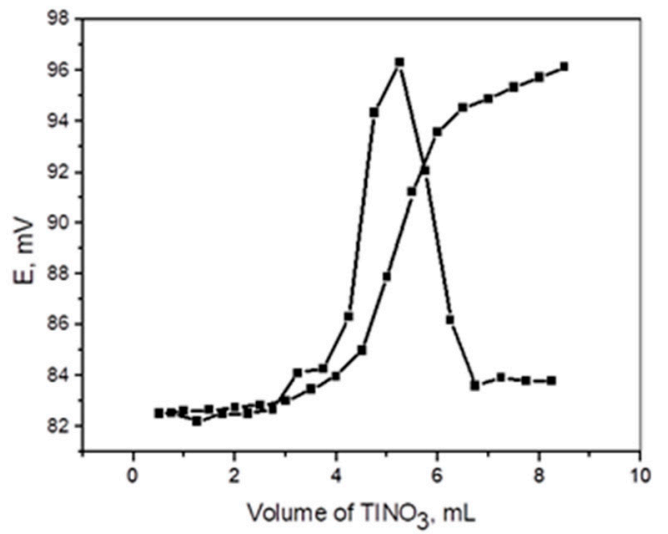

(a)

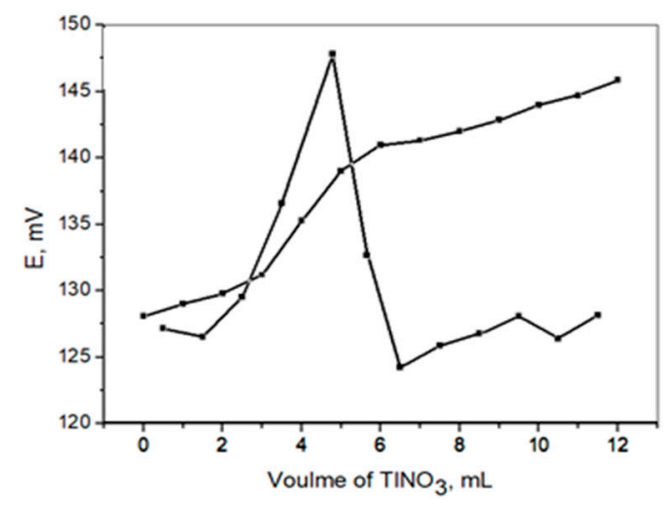

(c)

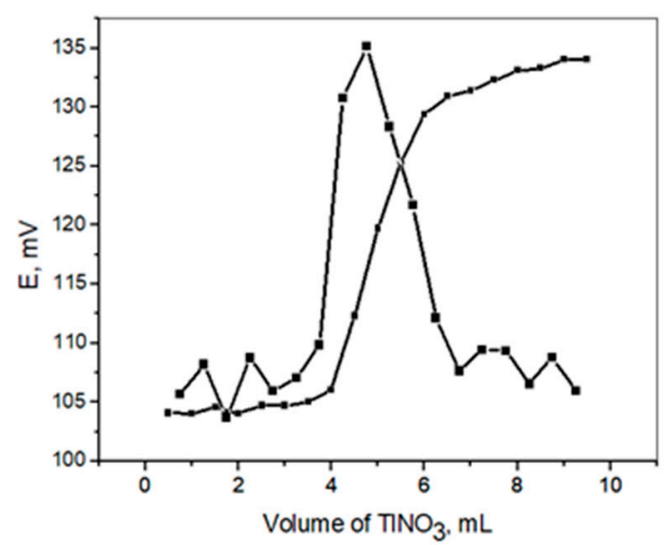

(b)

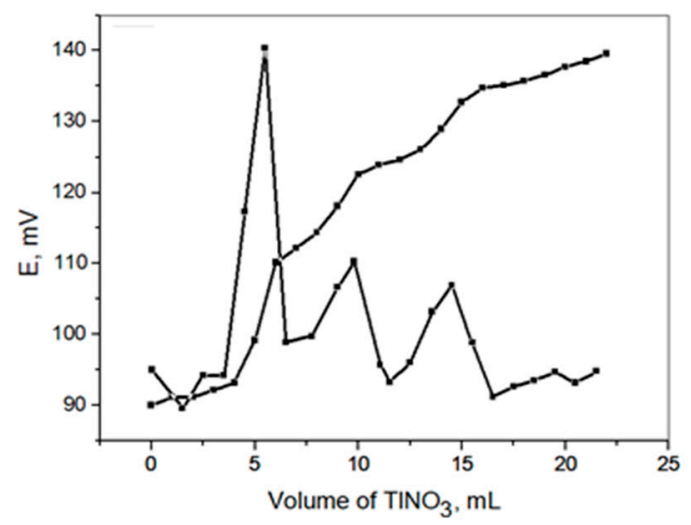

(d)

Figure 8. Potentiometric titration curves of $\mathrm{NaI}(\mathbf{a}), \mathrm{Na}_{2} \mathrm{~S}(\mathbf{b}), \mathrm{NaBr}(\mathbf{c})$, and a mixture of them (d) in solution $\left(50 \mathrm{~mL}\right.$ ) using $0.01 \mathrm{M} \mathrm{TINO}_{3}$ titrant (i.e, subfigure represents the $1^{\text {st }}$ derivative for the titration).

\section{Conclusions}

In summary, we presented here for the first time a solid-contact $\mathrm{Tl}^{+}$-ISE based on lipophilic multi-walled carbon nanotubes (MWCNTs) as an ion-to-electron transducer over a gold substrate with dibenzo18-crown- 6 as a neutral carrier. The optimized formulation of the membrane resulted in a linear concentration range of $4.5 \times 10^{-6}-7.0 \times 10^{-4} \mathrm{M}$ with a slope of $57.30 \mathrm{mV} / \mathrm{decade}$ and a limit of detection of $3.2 \times 10^{-7} \mathrm{M}$. The electrode revealed a stable potential over the $\mathrm{pH}$ range of 3.0-9.5. The introduction of a MWCNT layer as a high double layer capacitance to the gold plate electrode (GPE), offers the advantages of low electrical resistance and high response stability. The advantages and limitations of many of the previously suggested potentiometric solid-contact thallium sensors are given in Table 3. for comparison. It can be seen that the sensors suggested in the present work have several inherent advantages over many of those previously described. The proposed solid contact electrode is used successfully as an indicator electrode in potentiometric precipitation titrations for singly and ternary mixtures of sulfide, bromide, and iodide anions. 
Table 3. General characteristics of some potentiometric solid-contact Tl-membrane sensors.

\begin{tabular}{|c|c|c|c|c|c|c|c|c|}
\hline Sensing Material & Transducer & $\begin{array}{l}\text { Electrode } \\
\text { Material }\end{array}$ & Stability (Drift) & $\begin{array}{c}\text { Slope, } \\
\text { mV/Decade }\end{array}$ & $\begin{array}{l}\text { Detection } \\
\text { Limit, M }\end{array}$ & $\begin{array}{l}\text { Working pH } \\
\text { Range }\end{array}$ & $\begin{array}{c}\text { Selectivity Coefficient (log } \\
\left.\mathbf{K}^{\mathrm{Pot}}{ }_{\mathrm{Tl}, \mathrm{B}}\right)\end{array}$ & Ref. \\
\hline Calixarene derivatives & (3-octylthiophene) & $\mathrm{Au}$ & $<0.4 \mathrm{mV} / \mathrm{h}$ & 58.4 & $3.02 \times 10^{-8}$ & $4-9$ & $\begin{array}{l}\mathrm{Zn}^{2+}(-6.12), \mathrm{Ca}^{2+}(-6.01), \\
\mathrm{Ba}^{2+}(-5.84), \mathrm{Cu}^{2+}(-5.81), \\
\mathrm{Cd}^{+2}(-5.57), \mathrm{Al}^{3+}(-5.62), \\
\mathrm{Pb}^{2+}(-4.52), \mathrm{Li}^{+}(-3.97), \\
\mathrm{Na}^{+}(-3.74), \mathrm{H}^{+}(-3.66), \mathrm{K}^{+}(-2.77), \\
\mathrm{NH}_{4}^{+}(-2.71), \mathrm{Cs}^{+}(-2.17) \text { and } \\
\mathrm{Ag}^{+}(-1.16)\end{array}$ & [58] \\
\hline $4^{\prime}$-nitrobenzo-18-crown-6 & - & Graphite & - & 57.2 & $1.0 \times 10^{-8}$ & $5-14$ & $\begin{array}{l}\mathrm{K}^{+}(-0.98), \mathrm{Na}^{+}(-3.56) \\
\mathrm{Ca}^{2+}(-1.77) \text { and } \mathrm{Mg}^{2+}(-3.85)\end{array}$ & [59] \\
\hline $\begin{array}{l}N, N^{\prime} \text {-Dioctylethylenediamine- } \\
N, N^{\prime} \text {-disuccinic acid }\end{array}$ & Polyaniline & $\mathrm{Pt}$ & - & $56 \pm 2$ & $8.2 \times 10^{-8}$ & $4.7-9.0$ & - & {$[60]$} \\
\hline dibenzo-18-crown-6 & $\begin{array}{l}\text { Multi-walled } \\
\text { carbon } \\
\text { nanotubes }\end{array}$ & $\mathrm{Au}$ & $16 \pm 0.02 \mu \mathrm{V} / \mathrm{s}$ & $57.3 \pm 1.6$ & $3.2 \times 10^{-7}$ & $3.0-9.5$ & $\begin{array}{l}\mathrm{Zn}^{2+}(-6.50), \mathrm{Ca}^{2+}(-6.35), \\
\mathrm{Ba}^{2+}(-6.59), \mathrm{Cu}^{2+}(-6.31), \\
\mathrm{Cd}^{2+}(-6.7), \mathrm{Pb}^{2+}(-2.81), \\
\mathrm{Li}^{+}(-3.97), \mathrm{Na}^{+}(-6.48), \\
\mathrm{Ni}^{2+}(-6.48), \mathrm{K}^{+}(-2.12), \\
\mathrm{NH}_{4}{ }^{+}(-3.48), \mathrm{Mg}^{2+}(-6.62), \\
\mathrm{Fe}^{2+}(-6.62), \mathrm{Sr}^{2+}(-6.35) \text { and } \\
\mathrm{Ag}^{+}(-6.56)\end{array}$ & This work \\
\hline
\end{tabular}


Author Contributions: The listed authors contributed to this work as follows: M.A.F, A.H.K., S.M.A. and S.S.M.H. provided the concepts for the work, interoperated the results, carried out the experimental part and prepared the manuscript. A.H.K. and S.S.M.H. cooperated in the preparation of the manuscript and A.H.K., A.E.-G.E.A., and S.S.M.H. performed the revision before submission. A.E.-G.E.A. and M.A.A.-O. revealed the financial support for the work. All authors read and approved the final manuscript.

Funding: The authors are grateful to the Deanship of Scientifics Research, King Saud University for funding through Vice Deanship of Scientific Research Chairs

Conflicts of Interest: The authors declare no conflict of interest.

\section{References}

1. Escudero, L.B.; Wuilloud, R.G.; Olsina, R.A. Sensitive determination of thallium species in drinking and natural water by ionic liquid-assisted ion-pairing liquid-liquid microextraction and inductively coupled plasma mass spectrometry. J. Hazard. Mater. 2013, 244, 380-386. [CrossRef] [PubMed]

2. Chamsaz, M.; Arbab-Zavar, M.H.; Darroudi, A.; Salehi, T. Preconcentration of thallium (I) by single drop microextraction with electrothermal atomic absorption spectroscopy detection using dicyclohexano-18-crown-6 as extractant system. J. Hazard. Mater. 2009, 167, 597-601. [CrossRef] [PubMed]

3. Zitko, V. Toxicity and pollution potential of thallium. Sci. Total Environ. 1975, 4, 185-192. [CrossRef]

4. Nriagu, J. Thallium in the Environment, Advances in Environmental Sciences and Technology; Wiley: New York, NY, USA, 1998.

5. Moeschlin, S. Thallium poisoning. Clin. Toxicol. 1980, 17, 133-146. [CrossRef] [PubMed]

6. Lukaszewski, Z.; Zembrzuski, W.; Piela, A. Direct determination of ultra traces of thallium in water by flow-injection-differential-pulse anodic stripping voltammetry. Anal. Chim. Acta 1996, 318, 159-165. [CrossRef]

7. Ciszewski, A.; Wasiak, W.; Ciszewska, W. Hair analysis. Part 2. Differential pulse anodic stripping voltammetric determination of thallium in human hair samples of persons in permanent contact with lead in their workplace. Anal. Chim. Acta 1997, 343, 225-229. [CrossRef]

8. Lu, T.-H.; Yang, H.-Y.; Sun, I.W. Square-wave anodic stripping voltammetric determination of thallium (I) at a Nafion/mercury film modified electrode. Talanta 1999, 49, 59-68. [CrossRef]

9. Standard Methods for the Examination of Water and Wastewater, 19th ed.; American Public Health Association: Washington, DC, USA, 1995.

10. Skogerboe, R.; Dick, D.; Pavlica, D.; Lichte, F. Injection of samples into flames and plasmas by production of volatile chlorides. Anal. Chem. 1975, 47, 568-570. [CrossRef]

11. Floyd, M.A.; Fassel, V.; Winge, R.; Katzenberger, J.; D'silva, A. Inductively coupled plasma-atomic emission spectroscopy: A computer controlled, scanning monochromator system for the rapid sequential determination of the elements. Anal. Chem. 1980, 52, 431-438. [CrossRef]

12. Schramel, P.; Wendler, I.; Angerer, J. The determination of metals (antimony, bismuth, lead, cadmium, mercury, palladium, platinum, tellurium, thallium, tin and tungsten) in urine samples by inductively coupled plasma-mass spectrometry. Int. Arch. Occup. Environ. Health 1997, 69, 219-223. [CrossRef]

13. Fazelirad, H.; Taher, M.A. Ligandless, ion pair-based and ultrasound assisted emulsification solidified floating organic drop microextraction for simultaneous preconcentration of ultra-trace amounts of gold and thallium and determination by GFAAS. Talanta 2013, 103, 375-383. [CrossRef]

14. Marczenko, Z.; Kałowska, H.; Mojski, M. Extraction-spectrophotometric determination of thallium in high-purity indium. Talanta 1974, 21, 93-97. [CrossRef]

15. Ma, T.S.; Hassan, S.S.M. Organic Analysis Using Ion Selective Electrodes, Vol. I and II; Academic Press: London, UK, 1982.

16. Hassan, S.S.M.; Marzouk, S.A.M.; Mohamed, A.H.K.; Badawy, N.M. Novel dicyanoargentate polymeric membrane sensors for selective determination of cyanide ions. Electroanalysis 2004, 16, 298-303. [CrossRef]

17. Bakker, E.; Bühlmann, P.; Pretsch, E. Polymer Membrane Ion-Selective Electrodes-What are the Limits? Electroanalysis 1999, 11, 915-933. [CrossRef]

18. Ding, J.; Li, B.; Chen, L.; Qin, W. A Three-Dimensional Origami Paper-Based Device for Potentiometric Biosensing. Angew. Chem. Int. Ed. 2016, 55, 13033-13037. [CrossRef]

19. MaríaCuartero, M.; Crespo, G.A. All-solid-state potentiometric sensors: A new wave for in situ aquatic research. Curr. Opin. Electrochem. 2018, 10, 98-106. 
20. Cattrall, R.; Freiser, H. Coated wire ion-selective electrodes. Anal. Chem. 1971, 43, 1905-1906. [CrossRef]

21. Düzgün, A.; Zelada-Guillén, G.A.; Crespo, G.A.; Macho, S.; Riu, J.; Rius, F.X. Nanostructured materials in potentiometry. Anal. Bioanal. Chem. 2011, 399, 171-181. [CrossRef]

22. Amr, A.E.; Mohamed, A.; Al-Omar, M.A.; Kamel, A.H.; Elsayed, E.A. Single-Piece Solid Contact Cu ${ }^{2+}$-Selective Electrodes Based on a Synthesized Macrocyclic Calix[4]arene Derivative as a Neutral Carrier Ionophore. Molecules 2019, 24, 920. [CrossRef]

23. Lindner, E.; Gyurcsányi, R.E. Quality control criteria for solid-contact, solvent polymeric membrane ion-selective electrodes. J. Solid State Electrochem. 2009, 13, 51-68. [CrossRef]

24. Hu, J.; Stein, A.; Bühlmann, P. Rational design of all-solid-state ion-selective electrodes and reference electrodes. TrAC Trends Anal. Chem. 2016, 76, 102-114. [CrossRef]

25. Bakker, E.; Pretsch, E. Peer Reviewed: The New Wave of Ion-Selective Electrodes; ACS Publications: Washington, DC, USA, 2002; Volume 420-A.

26. Yin, T.; Qin, W. Applications of nanomaterials in potentiometric sensors. Trends Anal. Chem. 2013, 51, 79-86. [CrossRef]

27. Hu, J.; Zou, X.U.; Stein, A.; Buhlmann, P. Ion-selective electrodes with colloid-imprinted mesoporous carbon as solid contact. Anal. Chem. 2014, 86, 7111-7118. [CrossRef] [PubMed]

28. Kamel, A.H.; Galal, H.R.; Awaad, N.S. Cost-effective and handmade paper-based potentiometric sensingplatform for piperidine determination. Anal. Methods 2018, 10, 5406-5415. [CrossRef]

29. Antonisse, M.M.; Reinhoudt, D.N. Potentiometric anion selective sensors. Electroanalysis 1999, 11, $1035-1048$. [CrossRef]

30. Hassan, S.S.M.; GalalEldin, A.; Amr, A.E.; Al-Omar, M.A.; Kamel, A.H. Single-Walled Carbon Nanotubes (SWCNTs) as Solid-Contact in All-Solid-State Perchlorate ISEs: Applications to Fireworks and Propellants Analysis. Sensors 2019, 19, 2697. [CrossRef] [PubMed]

31. Liang, R.; Yin, T.; Qin, W. A simple approach for fabricating solid-contact ion-selective electrodes using nanomaterials as transducers. Anal. Chim. Acta 2015, 853, 291-296. [CrossRef] [PubMed]

32. Rius-Ruiz, F.X.; Crespo, G.A.; Bejarano-Nosas, D.; Blondeau, P.; Riu, J.; Rius, F.X. Potentiometric strip cell based on carbon nanotubes as transducer layer: Toward low-cost decentralized measurements. Anal. Chem. 2011, 83, 8810-8815. [CrossRef]

33. Ye, J.; Li, F.; Gan, S.; Jiang, Y.; An, Q.; Zhang, Q.; Niu, L. Using sp2-C dominant porous carbon sub-micrometer spheres as solid transducers in ion-selective electrodes. Electrochem. Commun. 2015, 50, 60-63. [CrossRef]

34. Li, J.; Yin, T.; Qin, W. An all-solid-state polymeric membrane $\mathrm{Pb}^{2+}$-selective electrode with bimodal pore $\mathrm{C} 60$ as solid contact. Anal. Chim. Acta 2015, 876, 49-54. [CrossRef]

35. Fouskaki, M.; Chaniotakis, N. Fullerene-based electrochemical buffer layer for ion-selective electrodes. Analyst 2008, 133, 1072-1075. [CrossRef]

36. Lai, C.Z.; Fierke, M.A.; Stein, A.; Buhlmann, P. Ion-selective electrodes with three-dimensionally ordered macroporous carbon as the solid contact. Anal. Chem. 2007, 79, 4621-4626. [CrossRef] [PubMed]

37. Li, J.; Yin, T.; Qin, W. An effective solid contact for an all-solid-state polymeric membrane $\mathrm{Cd}^{2+}$-selective electrode: Three-dimensional porousgraphene-mesoporous platinum nanoparticle composite. Sens. Actuators B 2017, 239, 438-446. [CrossRef]

38. Paczosa-Bator, B.; Cabaj, L.; Piech, R.; Skupien, K. Potentiometric sensors with carbon black supporting platinum nanoparticles. Anal. Chem. 2013, 85, 10255-10261. [CrossRef] [PubMed]

39. Yin, T.; Pan, D.; Qin, W. All-solid-state polymeric membrane ion-selective miniaturized electrodes based on a nanoporous gold film as solid contact. Anal. Chem. 2014, 86, 11038-11044. [CrossRef] [PubMed]

40. Woznica, E.; Wojcik, M.M.; Mieczkowski, J.; Maksymiuk, K.; Michalska, A. Dithizone Modified Gold Nanoparticles Films as Solid Contact for $\mathrm{Cu}^{2+}$-Ion-Selective Electrodes. Electroanalysis 2013, 25, 141-146. [CrossRef]

41. Zhou, M.; Gan, S.; Cai, B.; Li, F.; Ma, W.; Han, D. Effective solid contact for ion-selective electrodes: Tetrakis(4-chlorophenyl)borate ( $\mathrm{TB}^{-}$) anions doped nanocluster films. Anal. Chem. 2012, 84, 3480-3483. [CrossRef]

42. Guzinski, M.; Jarvis, J.M.; Pendley, B.D.; Lindner, E. Equilibration time of solid contact ion-selective electrodes. Anal. Chem. 2015, 87, 6654-6659. [CrossRef]

43. Zou, X.U.; Cheong, J.H.; Taitt, B.J.; Buhlmann, P. Solid contact ion-selective electrodes with a well-controlled Co(II)/Co(III) redox buffer layer. Anal. Chem. 2013, 85, 9350-9355. [CrossRef] 
44. Ebbesen, T.W. Production and purification of carbon nanotubes. In Carbon Nanotubes: Preparation and Properties; CRC Press: Boca Raton, FL, USA, 1997; pp. 139-162.

45. Li, J. Carbon nanotube applications: Chemical and physical sensors. In Carbon Nanotubes; CRC Press: Boca Raton, FL, USA, 2004; pp. 286-315.

46. Guibault, G.G.; Durst, R.A.; Frant, M.S.; Freiser, H.; Hansen, E.H.; Light, T.S.; Pungor, E.; Rechnitz, G.; Rice, N.M.; Rohm, T.J.; et al. Recommendations for Nomenclature of Ion-Selective Electrodes. Pure Appl. Chem. 1976, 48, 127-132.

47. Mi, Y.; Bakker, E. Determination of complex formation constants of lipophilic neutral ionophores in solvent polymeric membranes with segmented sandwich membranes. Anal. Chem. 1999, 71, 5279-5287. [CrossRef]

48. Qin, Y.; Mi, Y.; Bakker, E. Determination of complex formation constants of 18 neutral alkali and alkaline earth metal ionophores in poly (vinyl chloride) sensing membranes plasticized with bis (2-ethylhexyl) sebacate and o-nitrophenyloctylether. Anal. chim. Acta 2000, 421, 207-220. [CrossRef]

49. Eyal, E.; Rechnitz, G. Mechanistic studies on the valinomycin-based potassium electrode. Anal. Chem. 1971, 43, 1090-1093. [CrossRef]

50. Kimura, K.; Maeda, T.; Tamura, H.; Shono, T. Potassium-selective PVC membrane electrodes based on bis-and poly (crown ethers). J. Electroanal. Chem. Interfaces Electrochem. 1979, 95, 91-101. [CrossRef]

51. Maeda, T.; Kimura, K.; Shono, T. Solvent extraction of silver and thallium picrates with poly-and bis-(crown ether) s. Fresenius' Zeitschriftfüranalytische Chemie 1979, 298, 363-366. [CrossRef]

52. Liotta, C.L. Application of Macrocyclic Polydentate Ligands to Synthetic Transformations. In Synthetic Multidentate Macrocyclic Compounds; Elsevier: Amsterdam, The Netherlands, 1978; pp. 111-205.

53. Bakker, E. Determination of unbiased selectivity coefficients of neutral carrier-based cation-selective electrodes. Anal. Chem. 1997, 69, 1061-1069. [CrossRef]

54. Bakker, E.; Bühlmann, P.; Pretsch, E. Carrier-based ion-selective electrodes and bulk optodes. 1. General characteristics. Chem. Rev. 1997, 97, 3083-3132. [CrossRef]

55. Fibbioli, M.; Morf, W.E.; Badertscher, M.; de Rooij, N.F.; Pretsch, E. Potential drifts of solid-contacted ion-selective electrodes due to zero-current ion fluxes through the sensor membrane. Electroanalysis 2000, 12, 1286-1292. [CrossRef]

56. Bobacka, J. Potential stability of all-solid-state ion-selective electrodes using conducting polymers as ion-to-electron transducers. Anal. Chem. 1999, 71, 4932-4937. [CrossRef]

57. Zhang, X.; Song, X.; Gao, S.; Xu, Y.; Cheng, X.; Zhao, H.; Huo, L. Facile synthesis of yolk-shell MoO 2 microspheres with excellent electrochemical performance as a Li-ion battery anode. J. Mater. Chem. A 2013, 1, 6858-6864. [CrossRef]

58. Chester, R.; Sohail, M.; Ogden, M.I.; Mocerino, M.; Pretsch, E.; De Marco, R. A calixarene-based ion-selective electrode for thallium(I) detection. Anal. Chim. Acta 2014, 851, 78-86.

59. Kassim1, A.; Rezayi1, M.; Ahmadzadeh1, S.; Rounaghi2, G.; Mohajeri, M.; Yusof1, N.A.; Tee, T.W.; Heng, L.Y.; Abdullah, A. A Novel Ion-Selective Polymeric Membrane Sensor for Determining Thallium(I) With High Selectivity. Mater. Sci. Eng. 2011, 17, 012010. [CrossRef]

60. Kharitonov, S.V.; Zarembo, Y.V.; Zarembo, V.I. Novel Thallium(III) Solid-Contact Ion-Selective Electrode with Electropolymerized Transducer. Electroanalysis 2006, 18, 1354-1362. [CrossRef]

(C) 2019 by the authors. Licensee MDPI, Basel, Switzerland. This article is an open access article distributed under the terms and conditions of the Creative Commons Attribution (CC BY) license (http://creativecommons.org/licenses/by/4.0/). 